\title{
Peroxisome proliferator-activated receptors as stimulants of angiogenesis in cardiovascular disease and diabetes
}

This article was published in the following Dove Press journal:

Diabetes, Metabolic Syndrome and Obesity:Targets and Therapy

24 September 2009

Number of times this article has been viewed

\section{Cyrus V Desouza ${ }^{1,2}$ \\ Lindsey Rentschler' \\ Vivian Fonseca ${ }^{3}$}

'University of Nebraska Medical Center, ${ }^{2}$ Omaha VA Medical Center, Omaha, NE, USA; Scott \& White Medical Clinic/Texas A \& M College of Medicine, Temple, TX, USA
Correspondence: Cyrus Desouza Associate Professor, Diabetes, Endocrinology and Metabolism University of Nebraska Medical Center, Omaha VA Medical Center, Department of Medicine (III), 4101 Woolworth Avenue, Omaha NE, 68105, USA

$\mathrm{Tel}+\mathrm{I} 4029955506$

Fax +l 4029775602

Email cdesouza@unmc.edu

\begin{abstract}
The incidence of diabetes is directly related to the incidence of obesity, which is at epidemic proportions in the US. Cardiovascular disease is a common complication of diabetes, which results in high morbidity and mortality. Peroxisome proliferator-activated receptors (PPARs) are a group of nuclear hormone receptors that regulate lipid and glucose metabolism. PPAR- $\alpha$ agonists such as fenofibrate and PPAR- $\gamma$ agonists such as the thiozolidinediones have been used to treat dyslipidemia and insulin resistance in diabetes. Over the past few years research has discovered the role of PPARs in the regulation of inflammation, proliferation, and angiogenesis. Clinical trials looking at the effect of PPAR agonists on cardiovascular outcomes have produced controversial results. Studies looking at angiogenesis and proliferation in various animal models and cell lines have shown a wide variation in results. This may be due to the differential effects of PPARs on proliferation and angiogenesis in various tissues and pathologic states. This review discusses the role of PPARs in stimulating angiogenesis. It also reviews the settings in which stimulation of angiogenesis may be either beneficial or harmful.
\end{abstract}

Keywords: PPAR, VEGF, angiogenesis, cardiovascular

\section{Introduction}

Obesity, diabetes and cardiovascular disease are at epidemic proportions in the US. ${ }^{1,2}$ A large amount of clinical and basic research has been done to elucidate the pathophysiology of these disease processes. Peroxisome proliferator-activated receptors (PPARs) are a group of nuclear hormone receptors that control the expression of networks of genes regulating lipid metabolism and insulin resistance. ${ }^{3}$ They have been shown to affect inflammation, proliferation, immune function and angiogenesis. ${ }^{3}$ There are three PPAR isotypes, PPAR- $\alpha$, PPAR- $\beta / \delta$, and PPAR $-\gamma$. They form heterodimers with the retinoid $X$ receptors and bind to specific DNA sequences, called peroxisome proliferator response elements (PPRE), in the promoter regions of their target genes. PPARs exhibit isotype-specific tissue expression patterns. PPAR- $\alpha$ is primarily expressed in organs with significant fatty acid catabolism. PPAR- $\beta / \delta$ is expressed in nearly all cell types and the level of expression seems to depend on the amount of angiogenesis, cell proliferation, and differentiation occurring in that specific tissue. ${ }^{4}$ PPAR- $\gamma$ is found in adipose tissue and at lower levels in immune cells vascular tissue and some organs. PPAR- $\gamma$ exists in two protein isoforms, PPAR- $\gamma 1$ and PPAR- $\gamma 2$, with different lengths of the N-terminal. The PPAR- $\gamma 2$ isoform is predominantly expressed in adipose tissue, whereas PPAR- $\gamma 1$ is relatively widely expressed. ${ }^{5}$ Expression of each isoform is driven by a specific promoter that confers the distinct tissue expression patterns. There are also two other mRNA variants of PPAR- $\gamma$, proteins identical to PPAR- $\gamma 1$ : PPAR- $\gamma 3$, 
which is restricted to macrophages, adipose tissue, and colon, and PPAR- $\gamma 4$, the tissue distribution of which is unclear at this time. ${ }^{5}$ Human PPAR- $\gamma$ plays a critical physiological role as a central transcriptional regulator of both adipogenic and lipogenic programs. Its transcriptional activity is induced by the binding of endogenous and synthetic lipophilic ligands, which has led to the determination of many roles for PPAR- $\gamma$ in pathological states such as type 2 diabetes, atherosclerosis, inflammation, and cancer. The role of PPARs has traditionally been recognized as antiproliferative and antiangiogenic in a large number of disease states including cancer and cardiovascular disease. ${ }^{4}$ These studies have led to clinical trials with PPAR agonists to evaluate their benefits in cancer and cardiovascular disease. The results of some of these trials especially in cardiovascular disease have been mixed and hence controversial. The results obtained with a PPAR- $\gamma$ agonist pioglitazone do suggest a better impact on the lipid profile compared to rosiglitazone (the former lowers triglyceride significantly and has less adverse effects on low-density lipoprotein [LDL] cholesterol), and at least a mixed result (the primary composite endpoint was not reduced significantly but myocardial infarction, stroke, and death were reduced by $16 \%$ ), in an outcome trial - PROspective pioglitAzone Clinical Trial In macroVascular Events (PROACTIVE). ${ }^{6}$ Rosiglitazone on the other hand was found to increase cardiovascular events in a large restrospective analysis study. ${ }^{7}$ This has led to a lot of recent research into PPARs that is contrary to the traditional literature in their role as inhibitors of angiogenesis. This review will examine the role and evidence of PPARs as promoters of angiogenesis, the mechanisms involved, and the implications thereof.

\section{Angiogenesis, type 2 diabetes, and cardiovascular disease}

Angiogenesis is described as the formation of new capillaries from the existing vasculature. This process involves the breakdown of the extracellular matrix and formation of an endothelial tube. Angiogenesis is an important physiologic process in the female reproductive cycle, wound healing, and bone formation. Angiogenesis is also a crucial step in several disease states including cancer, diabetic retinopathy, rheumatoid arthritis, stroke, and ischemic coronary artery disease. ${ }^{8-10}$ Neoangiogenesis has harmful as well as beneficial effects in the setting of type 2 diabetes and cardiovascular disease. ${ }^{10}$ In the setting of diabetes, there is abnormal regulation and signaling of vascular endothelial growth factor (VEGF) and its receptor Flk-1. ${ }^{11}$ This may lead to increased levels of circulating VEGF, resulting in increased permeability of vascular structures throughout the body. In the retina, this results in the formation of protein-rich exudates containing VEGF that induces a local inflammatory response resulting in capillary sprouting. A similar process might take place in the arterial wall, thereby promoting capillary sprouting and plaque destabilization. ${ }^{12}$ At the same time, the lack of Flk-1 activation in endothelial cells and abnormal VEGFdependent activation of monocytes impair the arteriogenic response that requires monocyte recruitment, and monocyte and endothelial cell migration and proliferation. ${ }^{11}$ This could lead to a deficient angiogenic response in ischemic tissue. VEGF/Flk-1 signaling may also be required for bone marrow release of circulating endothelial progenitor cells that play a role in endothelial function and arteriogenesis. ${ }^{13}$ The abnormal release of endothelial progenitors could further reduce arteriogenic response. This has therapeutic implications in terms of vascularization and survival of skin grafts in patients with diabetes as well as vascularization of the ischemic myocardium. An important mechanism by which PPARs seem to regulate angiogenesis is via VEGF. ${ }^{11,12}$ It would therefore appear that PPARs have a role in regulating both beneficial and harmful effects of angiogenesis thereby leading to controversial results (Figure 1).

The other factor influencing the results of angiogenesis studies is the use of PPAR agonists that have pleotropic effects. PPAR- $\alpha$ agonists such as fibrates stimulate pathways that do not depend on PPAR- $\alpha .{ }^{14}$ PPAR- $\gamma$ agonists such as thiozolidinediones (TZDs) have PPAR $\gamma$ independent actions on proliferative and inflammatory pathways. ${ }^{14}$ Therefore to conclude that the effects of commonly used PPAR agonists on angiogenesis are specifically due to PPAR activation is at best controversial. ${ }^{15}$

\section{PPAR- $\alpha$ and angiogenesis Studies supporting antiproliferative properties of PPAR- $\alpha$}

PPAR- $\alpha$ agonists such as fibrates have long been used clinically to treat dyslipidemia. Several studies using fibrates have shown that they inhibit proliferation, angiogenesis and tumor growth. ${ }^{16}$ In the Fenofibrate Intervention in Event Lowering in Diabetes (FIELD) study fenofibrate treatment demonstrated a significant $30 \%$ reduction in the need for laser therapy in patients with and without known diabetic retinopathy, and more particularly in the first course of laser treatment for both macular edema and proliferative retinopathy. ${ }^{17}$ In addition, fenofibrate treatment was associated with less albuminuria progression and reduced risk of 


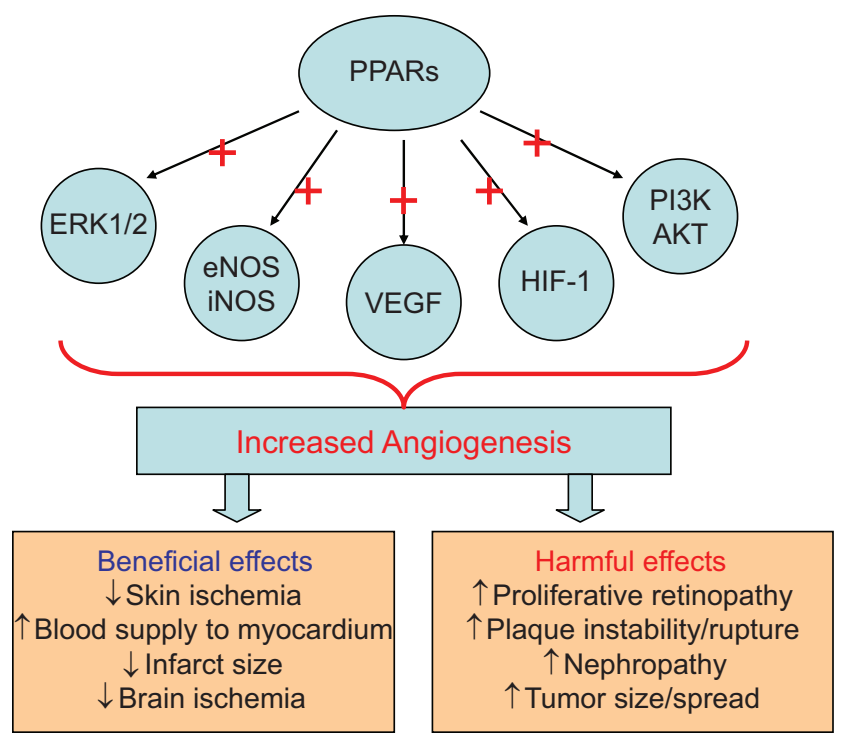

Figure I Mechanisms by which PPARs effect angiogenesis.

non traumatic distal amputations. ${ }^{17}$ Pozzi et al treated mice injected with tumor cells with Wy-14643, a selective PPAR- $\alpha$ ligand. Wy-14643 treated mice showed marked reductions in tumor growth and vascularization. ${ }^{15}$ All these responses were absent in PPAR- $\alpha^{-/}$mice thus suggesting that these antiproliferative effects might be PPAR $\alpha$ mediated. Several other animal studies show the antiproliferative properties of fenofibrate (Table 1). ${ }^{18,19}$

\section{Studies supporting proangiogenic role of PPAR- $\alpha$}

However recent studies using specific non fibrate PPAR- $\alpha$ agonists or PPAR- $\alpha$ knockout mice have shown that PPAR- $\alpha$ may be involved in stimulating angiogenesis (Table 1). Biscetti et al used a selective synthetic PPAR- $\alpha$ agonist to demonstrate that activation of PPAR- $\alpha$ leads to endothelial tube formation in an endothelial/interstitial cell co-culture assay. ${ }^{20}$ This study also showed that neovascularization occurs with PPAR $\alpha$ activation in a murine corneal angiogenic model. In contrast no angiogenesis was found in PPAR- $\alpha$ knockout mice treated with this synthetic agonist. ${ }^{20}$ In another study iloprost, an angiogenesis agent, was not able to induce angiogenesis in PPAR- $\alpha$ knockout mice. ${ }^{21}$ In both these studies angiogenesis was stimulated through a PPAR- $\alpha$ induced VEGF upregulation. Fauconnet et al showed that activation of PPAR- $\alpha$ increased VEGF expression via a transcriptional activation of the VEGF promoter. ${ }^{22}$

Although the majority of studies point towards the antiproliferative, antiangiogenic properties of PPAR- $\alpha$, this may be due to the use of fibrates as agonists in these experiments.
A lot more research needs to be done using methods such as spontaneous PPAR- $\alpha$ activation, overexpression, silencing and knockout mice, rather than using chemical agonists and antagonists which might have pleotropic effects unrelated to PPAR- $\alpha$.

\section{PPAR- $\beta / \delta$ and angiogenesis}

Recently developed synthetic ligands and genetically modified mice models for PPAR- $\beta / \delta$ have increased our knowledge of its role in metabolism, inflammation, and angiogenesis. A large range of naturally occurring ligands bind to PPAR- $\beta / \delta$, including 14 to 18 carbon saturated fatty acids, 16 to 20 carbon polyunsaturated fatty acids, prostaglandin A1 and carbaprostacyclin. ${ }^{23}$ However, whether any of these are physiological ligands is controversial. Retinoic acid and several synthetic ligands can also specifically activate PPAR- $\beta / \delta .^{24}$

\section{Studies supporting proangiogenic role of PPAR- $\beta / \delta$}

Studies generally show that PPAR- $\beta / \delta$ may be involved in stimulating angiogenesis (Table 1$)$. The PPAR- $\beta / \delta$ agonist GW501516 stimulated human umbilical vein endothelial cells proliferation and increased VEGF expression. ${ }^{25}$ In another experiment GW501516 increased angiogenesis and promoted endothelial tube formation in a PPAR- $\beta / \delta$ and VEGF dependent manner. ${ }^{26}$ Gaudel et al showed that PPAR- $\beta / \delta$ activation resulted in a 1.5 -fold increase in capillary number in mouse skeletal muscle. ${ }^{27}$ In a study of tissue samples obtained from human colorectal carcinomas and matched adjacent tissues, VEGF expression, microvascular density, and venous vessel invasion increased as the expression of PPAR- $\beta / \delta$ and cyclooxygenase (COX)- 2 increased. ${ }^{28}$ He et al performed a set of experiments in human endothelial progenitor cells (EPCs) which showed that impaired tube formation and cell proliferation induced by inactivation of COX-1 were rescued by treatment with a PPAR- $\beta / \delta$ agonist. Furthermore, transfection of PPAR- $\beta / \delta$ siRNA into EPCs decreased the capillary formation in vivo after transplantation of these human EPCs into nude mice. ${ }^{29}$ Growth of syngeneic PPAR- $\beta / \delta$ wild-type tumors was suppressed in PPAR- $\beta / \delta^{-/}$ mice, along with a decreased blood flow and hyperplastic vasculature. ${ }^{30}$ Muller et al reviewed a number of recent studies that suggest that stromal PPAR- $\beta / \delta$ regulates tumor endothelial cell proliferation and promotes differentiation leading to the properly orchestrated events required for tumor blood vessel formation. ${ }^{31}$ These data do suggest that PPAR- $\beta / \delta$ may indeed be proangiogenic under certain conditions. 
Table I Effect of PPARs on angiogenesis

\begin{tabular}{|c|c|c|c|c|c|c|}
\hline \multirow[t]{2}{*}{ Receptor } & \multicolumn{3}{|l|}{ Stimulation } & \multicolumn{3}{|l|}{ Inhibition } \\
\hline & Type of cells/model & Study outcome & Ref & Type of cells/model & Study outcome & Ref \\
\hline \multirow[t]{5}{*}{ PPAR- $\alpha$} & $\begin{array}{l}\text { Endothelial/interstitial } \\
\text { cell co-culture assay }\end{array}$ & $\begin{array}{l}\uparrow \text { endothelial tube } \\
\text { formation }\end{array}$ & 17 & Human DM2 patients & $\downarrow$ proliferative retinopathy & 14 \\
\hline & & & & & $\downarrow$ albuminuria & \\
\hline & $\begin{array}{l}\text { Murine corneal } \\
\text { angiogenic model }\end{array}$ & $\uparrow$ neovascularization & 17 & $\begin{array}{l}\text { Porcine model } \\
\text { coronary }\end{array}$ & $\downarrow$ neointimal hyperplasia & 15 \\
\hline & $\begin{array}{l}\text { PPAR- } \alpha \text { knockout } \\
\text { mice }\end{array}$ & $\begin{array}{l}\uparrow \text { VEGF expression } \\
\uparrow \text { angiogenesis }\end{array}$ & 18 & Mouse model & $\begin{array}{l}\downarrow \text { vascular smooth muscle } \\
\text { proliferation }\end{array}$ & 16 \\
\hline & Bladder cancer cells & $\uparrow$ VEGF expression & 19 & $\begin{array}{l}\text { Mouse model } \\
\text { cancer }\end{array}$ & $\begin{array}{l}\downarrow \text { angiogenesis } \\
\downarrow \text { VEGF expression }\end{array}$ & $59^{66}$ \\
\hline \multirow[t]{5}{*}{ PPAR- $\beta / \delta$} & HUVEC & $\begin{array}{l}\uparrow \text { endothelial cell } \\
\text { Proliferation }\end{array}$ & 22 & $\begin{array}{l}\text { Rats - ischemic } \\
\text { injury model }\end{array}$ & $\begin{array}{l}\downarrow \text { testicular ischemic injury } \\
\downarrow \text { ERKI/2 activation }\end{array}$ & $60^{67}$ \\
\hline & HUVEC & $\begin{array}{l}\uparrow \text { endothelial tube } \\
\text { formation }\end{array}$ & 23 & $\begin{array}{l}\text { Rat vascular smooth } \\
\text { muscle cells }\end{array}$ & $\begin{array}{l}\downarrow \text { proliferation } \\
\downarrow \text { migration }\end{array}$ & $61^{68}$ \\
\hline & $\begin{array}{l}\text { Murine skeletal } \\
\text { muscle }\end{array}$ & $\uparrow$ capillary number & 24 & $\begin{array}{l}\text { Human } \mathrm{HaCaT} \\
\text { keratinocytes }\end{array}$ & $\downarrow$ cell proliferation & $62^{69}$ \\
\hline & $\begin{array}{l}\text { Human colorectal } \\
\text { tumor cells }\end{array}$ & $\begin{array}{l}\uparrow \text { VEGF expression } \\
\uparrow \text { vessel invasion }\end{array}$ & 25 & $\begin{array}{l}\text { Mouse cremasteric } \\
\text { endothelium }\end{array}$ & $\begin{array}{l}\downarrow \text { leukocyte adhesion and } \\
\text { migration } \\
\downarrow \text { ICAM-I and E-selectin }\end{array}$ & $63^{70}$ \\
\hline & EPCs & $\begin{array}{l}\uparrow \text { endothelial tube } \\
\text { formation } \\
\uparrow \text { endothelial cell } \\
\text { proliferation }\end{array}$ & 26 & & & \\
\hline \multirow[t]{5}{*}{ PPAR- $\gamma$} & $\begin{array}{l}\text { Bovine aortic } \\
\text { endothelial cells }\end{array}$ & $\begin{array}{l}\uparrow \text { VEGF expression } \\
\uparrow N O \text { production }\end{array}$ & 38 & $\begin{array}{l}\text { Choroidal } \\
\text { endothelial cells }\end{array}$ & $\begin{array}{l}\downarrow \text { endothelial cell proliferation } \\
\uparrow \text { differentiation }\end{array}$ & 31 \\
\hline & $\begin{array}{l}\text { Cultured rat } \\
\text { myofibroblasts }\end{array}$ & $\begin{array}{l}\uparrow \text { endothelial tube } \\
\text { formation } \\
\uparrow \text { VEGF expression }\end{array}$ & 39 & HUVEC & $\begin{array}{l}\downarrow \text { endothelial cell prolifera- } \\
\text { tion and migration } \\
\downarrow \text { endothelial tube formation }\end{array}$ & 34 \\
\hline & Murine adipose tissue & $\begin{array}{l}\uparrow \text { VEGF expression } \\
\uparrow \text { angiopoeitin- } 4\end{array}$ & 40 & Endothelial cells & $\uparrow$ apoptosis & 35 \\
\hline & $\begin{array}{l}\text { Rat cerebral } \\
\text { ischemia model }\end{array}$ & $\begin{array}{l}\downarrow \text { infarct size } \\
\uparrow \text { eNOS } \\
\downarrow \text { caspase-3 }\end{array}$ & 41 & Rat astrocytes & $\begin{array}{l}\uparrow \text { apoptosis } \\
\uparrow \text { differentiation }\end{array}$ & 36 \\
\hline & Humans with DM2 & $\begin{array}{l}\uparrow \text { VEGF, } \uparrow \text { IL-8 } \\
\uparrow \text { angiogenin }\end{array}$ & 44 & Rat carotid & $\downarrow$ neointimal 32 hyperplasia & 32 \\
\hline
\end{tabular}

Abbreviations: DM2, diabetes mellitus type 2; EPCs, human endothelial progenitor cells; HUVEC, human umbilical vein endothelial cells; VEGF, vascular endothelial growth factor.

Mechanisms by which PPAR- $\beta / \delta$ activation either suppresses or stimulates angiogenesis are not well studied. A large number of studies implicate increased VEGF and Flt-1 expression. ${ }^{32,33}$

\section{PPAR- $\gamma$ and angiogenesis}

PPAR- $\gamma$ is probably the most studied PPAR, likely due to the use and development of several PPAR- $\gamma$ agonists such as thiozolidinediones in the treatment of type 2 diabetes. Endogenous ligands for PPAR- $\gamma$ include long chain polyunsaturated fatty acids and their derivatives, 15-deoxy- $\Delta 12$, 14-prostaglandin $\mathrm{J}_{2}(15 \mathrm{~d}-\mathrm{PGJ} 2) .{ }^{4}$ Other natural ligands include nitrolinoleic acids. $15 \mathrm{~d}-\mathrm{PGJ} 2$ has been found to upregulate the expression of PPAR- $\gamma$ and also the DNA binding and transcriptional activity ${ }^{34}$ Synthetic ligands include TZDs and various nonsteroidal anti-inflammatory drugs. ${ }^{35}$

\section{Studies supporting antiproliferative properties of PPAR- $\gamma$}

PPAR- $\gamma$ has widespread effects involving, inflammation, atherosclerosis, obesity, diabetes, and cancer. ${ }^{36}$ PPAR- $\gamma$ 
agonists directly inhibit tumor cell growth, induce cell differentiation, and apoptosis in various cancer types (Table 1). ${ }^{37}$ TZDs have been shown to decrease post angioplasty neointimal hyperplasia in both animals and humans (Table 1). ${ }^{38,39}$ PPAR- $\gamma$ ligands have been shown to inhibit and stimulate angiogenesis (Table 1). Inhibition by PPAR- $\gamma$ ligands can occur through direct effects on the endothelium or through indirect effects on the net balance of proangiogenic and antiangiogenic mediators. ${ }^{37}$ PPAR- $\gamma$ expressed in choroidal endothelial cells inhibits the differentiation and proliferation of those cells. ${ }^{38,39}$ Rosiglitazone inhibited endothelial cell proliferation and migration and decreased VEGF-induced tubule formation in human umbilical vein endothelial cells. ${ }^{40,41}$ In another study PPAR- $\gamma$ ligands stimulated endothelial cell caspase-mediated apoptosis. $^{42} 15 \mathrm{~d}-\mathrm{PGJ} 2$, an endogenous ligand of PPAR- $\gamma$, induces growth inhibition, differentiation, and apoptosis of tumor cells. ${ }^{43}$ PPAR- $\gamma$ activation interrupts NF-k $\beta$ signaling with subsequent blockade of proinflammatory gene expression. ${ }^{43}$ Pioglitazone and rosiglitazone inhibit the effects of growth factors such as bFGF and VEGF. Endothelial cell migration is also inhibited by both compounds. ${ }^{44}$ Thus natural and synthetic ligands of PPAR- $\gamma$ exhibit antiangiogenic properties under certain conditions.

\section{Studies supporting proangiogenic role of PPAR- $\gamma$}

However, PPAR- ligands have also been shown to stimulate the angiogenic pathway (Table 1). In bovine aortic endothelial cells, prolonged treatment with troglitazone increased VEGF and endothelial nitric oxide (NO) production with no change in endothelial nitric oxide synthase (eNOS) expression. ${ }^{45}$ In cultured rat myofibroblasts, activation of PPAR $-\gamma$ by troglitazone and 15-dPGJ2 induced VEGF expression and augmented tubule formation. ${ }^{46}$ In mice treated with rosiglitazone, angiogenesis was stimulated in adipose tissue with increased expression of VEGF and angiopoeitin-4 (Ang-4). Ang-4 stimulated endothelial cell growth and tubule formation. ${ }^{47}$ In rats with focal cerebral ischemia, rosiglitazone treatment enhanced neurologic improvement and reduced the infarct size by reducing caspase-3 activity, increasing the number of endothelial cells, and increasing eNOS expression. ${ }^{48}$ In the setting of diabetes, PPAR- $\gamma$ agonists may promote revascularization of ischemic tissue. Diabetic mice with induced unilateral hind limb ischemia, when treated with pioglitazone showed normalization of VEGF, upregulation of eNOS activity, and partial restoration of blood flow recovery. ${ }^{49}$ In mice treated with pioglitazone,
VEGR-receptor-2 positive EPCs were upregulated and migratory capacity was increased. In vivo angiogenesis was increased 2-fold. ${ }^{50}$ In an endothelial/interstitial cell co-culture assay, treatment with PPAR- $\gamma$ agonists stimulated production of VEGF. In the same study, corneas treated with the same PPAR- $\gamma$ agonists increased phosphorylation of eNOS. ${ }^{20}$

Few studies have evaluated angiogenesis in humans. Pioglitazone treatment has been shown to increase serum VEGF, IL-8, and angiogenin levels in patients with type 2 diabetes. ${ }^{51}$ In another study thiozolidinedione use in patients with type 2 diabetes was associated with diabetic macular edema. ${ }^{52}$

\section{PGC-I $\alpha$ and angiogenesis}

Peroxisome proliferator-activated receptor (PPAR)-gamma coactivator 1alpha (PGC-1 $\alpha)$ is a nuclear transcriptional coactivator that regulates several important metabolic processes, including mitochondrial biogenesis, adaptive thermogenesis, respiration, insulin secretion and gluconeogenesis. ${ }^{53}$ PGC- $1 \alpha$ also co-activates PPAR- $\alpha$, PPAR- $\beta / \delta$, and PPAR- $\gamma$ which are important transcription factors of genes regulating lipid and glucose metabolism. ${ }^{53}$ Recently Arany and colleagues have shown that PGC- $1 \alpha$ stimulates angiogenesis in ischemic tissues. Using a combination of muscle cell assays and genetically modified mice that over or underexpess PGC- $1 \alpha$, they showed that PGC- $1 \alpha$ is a powerful inducer of VEGF expression. PGC-1 $\alpha$ did not involve HIF-1 but activated the nuclear receptor, estrogenrelated receptor- $\alpha$ (ERR- $\alpha){ }_{.}^{33}$ PGC- $1 \alpha^{-/}$mice are viable, suggesting that PGC- $1 \alpha$ is not essential in embryonic vascularization but they show a striking failure to reconstitute blood flow in a normal manner to the limb after an ischaemic insult. ${ }^{54}$ Transgenic expression of PGC- $1 \alpha$ in skeletal muscle is protective against ischemic insults. This suggests that PGC- $1 \alpha$ plays a more important role in a disease state rather than a physiologically healthy state.

\section{Mechanisms by which PPARs may stimulate angiogenesis}

PPARs seem to have a protective role in ischemic tissues, including brain, cardiac and skin. A part of this may be by stimulating angiogenesis and improving blood supply. Hypoxia is a trigger for the development of angiogenesis. One of the key mediators in hypoxia-induced angiogenesis is hypoxia inducible factor (HIF-1), which is induced in hypoxic cells and binds to hypoxia response element (HRE). HIF-1 mediates the transcriptional activation of several genes that promote angiogenesis, including VEGF, angiopoeitin (Ang-1, Ang-2), and matrix metalloproteinases (MMP-2, MMP-9). ${ }^{55}$ 
15-deoxy-delta(12,14)-prostaglandin J(2) (15d-PGJ(2)), a PPAR- $\gamma$ agonist, has been shown to induce HIF-1 expression and thereby angiogenesis (Figure 1). ${ }^{34}$ However pioglitazone has been shown to suppress the induction of HIF-1. ${ }^{56}$ Conditions that influence the stimulation or suppression of HIF activation by PPAR- $\gamma$ are largely unknown.

Several studies suggest that eNOS synthase activation is required for angiogenesis that may be protective under certain conditions. ${ }^{57-59}$ In one study pioglitazone reduced the myocardial infarct size in part via activation of eNOS. ${ }^{60}$ PPAR- $\alpha$ activation has also been shown to protect the type 2 diabetic rat myocardium against ischemia-reperfusion injury via the activation of the NO pathway (Table 1, Figure 1). ${ }^{61}$ However, stimulation of the inducible nitric oxide (iNOS) pathway can lead to undesirable angiogenesis that may be contribute to pathological states such as proliferative retinopathy. PPARs in fact have been shown to suppress iNOS expression, thereby suppressing undesirable angiogenesis. ${ }^{62,63}$ Here again the factors that allow for activation of eNOS and suppression of iNOS is largely unknown.

The most studied pathway by which PPARs may stimulate angiogenesis is the VEGF pathway. VEGF can stimulate angiogenesis via stimulation of the ERK1/2 pathway. PPAR- $\beta / \delta$ activation has been shown to increase VEGF expression and thereby stimulate angiogenesis (Figure 1). ${ }^{26}$ In some studies PPAR- $\alpha$ and PPAR- $\gamma$ have also been shown to increase VEGF expression. ${ }^{47,48}$ However the majority of studies still show that PPAR activation suppresses VEGF expression. The end result of whether PPAR activation suppresses or stimulates VEGF expression seems to lie in the pathological condition in which its actions are observed (Figure 1). It is likely that PPAR activation results in increased VEGF expression in conditions where new blood vessel formation is required, such as ischemic skin flaps, brain, or cardiac tissue ischemia. On the other hand, pathological angiogenesis such as in the eye or within an atherosclerotic plaque is suppressed by PPAR activation via a suppression of VEGF (Figure 1).

Recently some studies indicate that PPARs may increase the expression and activation of the phosphatidylinositol3-kinase (PI3K/AKT) pathway. ${ }^{61,64}$ The PI3K/AKT pathway stimulates angiogenesis. ${ }^{59,65}$ Again the majority of studies show that PPAR activation inhibits PI3K/AKT activation.

It is very likely that a large amount of variation found in different studies is due to the use of agonists and antagonists of the PPAR receptors that exhibit direct PPAR-independent effects. Most study designs do not distinguish between direct effects and indirect effects of various pharmacological agonists/antagonist used. Fibrates and TZDs have both been shown to have direct independent effects on inflammation, proliferation and angiogenesis. Hence it is difficult to conclude that all the pro and antiangiogenic effects seen in various studies are a result of PPAR activation exclusively.

\section{Clinical significance and conclusions}

Some compounds such as TZDs and fibrates are routinely used in patients with diabetes, dyslipidemia, and cardiovascular disease. Other compounds such as partial agonists or dual agonists of PPAR- $\alpha$ and PPAR- $\gamma$ are in development. The effects of these newer compounds, on angiogenesis and cardiovascular disease are yet to be determined. Current evidence from clinical trials suggest a mixed picture. TZD treatment in patients with type 2 diabetes has been shown to be associated with macular edema. On the other hand, the FIELD study using fenofibrate showed a decrease in the need for laser treatments in patients with diabetic retinopathy. The PROACTIVE study showed that pioglitazone trended to decrease certain cardiovascular endpoints. In some studies, rosiglitazone increased the risk of cardiovascular events. In other studies such as ACCORD and VADT, TZD treatment was not associated with increased cardiovascular event risk. Several factors, including the study design, PPAR receptor affinity, and the PPAR-independent actions of these compounds, possibly play a role in the differences in results seen. The duration of the pathological state and the vasculature of the effected organ likely play a role in whether PPARs prove beneficial or harmful. In conclusion it may be prudent to summarize that at this point the evidence suggests that PPARs can either stimulate or inhibit angiogenesis, depending on the biological context and pathological process.

\section{Disclosures}

The authors declare no conflicts of interest.

\section{References}

1. Wee CC, Hamel MB, Huang A, Davis RB, Mittleman MA, McCarthy EP. Obesity and undiagnosed diabetes in the US. Diabetes Care. 2008;31:1813-1815.

2. Westphal SA. Obesity, abdominal obesity, and insulin resistance. Clin Cornerstone. 2008;9:23-31.

3. Calkin AC, Thomas MC. PPAR agonists and cardiovascular disease in diabetes. PPAR Res. 2008:245410.

4. Duan SZ, Ivashchenko CY, Usher MG, Mortensen RM. PPAR-gamma in the cardiovascular system. PPAR Res. 2008:745804.

5. Knouff C, Auwerx J. Peroxisome proliferator-activated receptorgamma calls for activation in moderation: lessons from genetics and pharmacology. Endocr Rev. 2004;25:899-918.

6. Erdmann E, Dormandy J, Wilcox R, Massi-Benedetti M, Charbonnel B. PROactive 07: pioglitazone in the treatment of type 2 diabetes: results of the PROactive study. Vasc Health Risk Manag. 2007;3:355-370. 
7. Nissen SE, Wolski K. Effect of rosiglitazone on the risk of myocardial infarction and death from cardiovascular causes. N Engl J Med. 2007; 356:2457-2471.

8. Folkman J. Angiogenesis in cancer, vascular, rheumatoid and other disease. Nat Med. 1995;1:27-31.

9. Carmeliet P, Baes M. Metabolism and therapeutic angiogenesis. N Engl J Med. 2008;358:2511-2512.

10. Martin A, Komada MR, Sane DC. Abnormal angiogenesis in diabetes mellitus. Med Res Rev. 2003;23:117-145.

11. Simons M. Angiogenesis, arteriogenesis, and diabetes: paradigm reassessed? J Am Coll Cardiol. 2005;46:835-837.

12. Qaum T, Xu Q, Joussen AM, et al. VEGF-initiated blood-retinal barrier breakdown in early diabetes. Invest Ophthalmol Vis Sci. 2001;42: 2408-2413.

13. Pitchford SC, Furze RC, Jones CP, Wengner AM, Rankin SM. Differential mobilization of subsets of progenitor cells from the bone marrow. Cell Stem Cell. 2009;4:62-72.

14. Jandeleit-Dahm KA, Calkin A, Tikellis C, Thomas M. Direct antiatherosclerotic effects of PPAR agonists. Curr Opin Lipidol. 2009;20:24-29.

15. Pozzi A, Ibanez MR, Gatica AE, et al. Peroxisomal proliferator-activated receptor-alpha-dependent inhibition of endothelial cell proliferation and tumorigenesis. J Biol Chem. 2007;282:17685-17695.

16. Grabacka M, Reiss K. Anticancer properties of PPARalpha effects on cellular metabolism and inflammation. PPAR Res. 2008:930705.

17. Scott R, O'Brien R, Fulcher G, et al. Effects of fenofibrate treatment on cardiovascular disease risk in 9,795 individuals with type 2 diabetes and various components of the metabolic syndrome: the Fenofibrate Intervention and Event Lowering in Diabetes (FIELD) study. Diabetes Care. 2009;32:493-498.

18. Kasai T, Miyauchi K, Yokoyama T, Aihara K, Daida H. Efficacy of peroxisome proliferative activated receptor (PPAR)-alpha ligands, fenofibrate, on intimal hyperplasia and constrictive remodeling after coronary angioplasty in porcine models. Atherosclerosis. 2006;188: 274-280.

19. Gizard F, Amant C, Barbier O, et al. PPAR alpha inhibits vascular smooth muscle cell proliferation underlying intimal hyperplasia by inducing the tumor suppressor p16INK4a. J Clin Invest. 2005; 115:3228-3238.

20. Biscetti F, Gaetani E, Flex A, et al. Selective activation of peroxisome proliferator-activated receptor (PPAR)alpha and PPAR gamma induces neoangiogenesis through a vascular endothelial growth factor-dependent mechanism. Diabetes. 2008;57:1394-1404.

21. Biscetti F, Gaetani E, Flex A, et al. Peroxisome proliferator-activated receptor alpha is crucial for iloprost-induced in vivo angiogenesis and vascular endothelial growth factor upregulation. J Vasc Res. 2009;46:103-108.

22. Fauconnet S, Lascombe I, Chabannes E, et al. Differential regulation of vascular endothelial growth factor expression by peroxisome proliferator-activated receptors in bladder cancer cells. J Biol Chem. 2002;277:23534-23543.

23. Wang N. PPAR-delta in Vascular Pathophysiology. PPAR Res. 2008:164163.

24. Berry DC, Noy N. All-trans-retinoic acid represses obesity and insulin resistance by activating both PPAR $\{$ beta $\} /\{$ delta $\}$ and RAR. Mol Cell Biol. 2009;29:3286-3296.

25. Stephen RL, Gustafsson MC, Jarvis M, et al. Activation of peroxisome proliferator-activated receptor delta stimulates the proliferation of human breast and prostate cancer cell lines. Cancer Res. 2004;64: 3162-3170.

26. Piqueras L, Reynolds AR, Hodivala-Dilke KM, et al. Activation of PPARbeta/delta induces endothelial cell proliferation and angiogenesis. Arterioscler Thromb Vasc Biol. 2007;27:63-69.

27. Gaudel C, Schwartz C, Giordano C, Abumrad NA, Grimaldi PA. Pharmacological activation of PPARbeta promotes rapid and calcineurindependent fiber remodeling and angiogenesis in mouse skeletal muscle. Am J Physiol Endocrinol Metab. 2008;295:E297-E304.
28. Yoshinaga M, Kitamura Y, Chaen T, et al. The simultaneous expression of peroxisome proliferator-activated receptor delta and cyclooxygenase-2 may enhance angiogenesis and tumor venous invasion in tissues of colorectal cancers. Dig Dis Sci. 2009;54:1108-1114.

29. He T, Lu T, d'Uscio LV, Lam CF, Lee HC, Katusic ZS. Angiogenic function of prostacyclin biosynthesis in human endothelial progenitor cells. Circ Res. 2008;103:80-88.

30. Muller-Brusselbach S, Komhoff M, Rieck M, et al. Deregulation of tumor angiogenesis and blockade of tumor growth in PPARbetadeficient mice. Embo J. 2007;26:3686-3698.

31. Muller R, Komhoff M, Peters JM, Muller-Brusselbach S. A Role for PPARbeta/delta in Tumor Stroma and Tumorigenesis. PPAR Res. 2008:534294.

32. Wang D, Wang H, Guo Y, et al. Crosstalk between peroxisome proliferator-activated receptor delta and VEGF stimulates cancer progression. Proc Natl Acad Sci US A. 2006;103:19069-19074.

33. Hollingshead HE, Killins RL, Borland MG, et al. Peroxisome proliferator-activated receptor-beta/delta (PPARbeta/delta) ligands do not potentiate growth of human cancer cell lines. Carcinogenesis. 2007;28:2641-2649.

34. Kim EH, Surh YJ. 15-deoxy-Delta12, 14-prostaglandin J2 as a potential endogenous regulator of redox-sensitive transcription factors. Biochem Pharmacol. 2006;72:1516-1528.

35. Lehmann JM, Lenhard JM, Oliver BB, Ringold GM, Kliewer SA. Peroxisome proliferator-activated receptors alpha and gamma are activated by indomethacin and other non-steroidal anti-inflammatory drugs. J Biol Chem. 1997;272:3406-3410.

36. Pershadsingh HA. Peroxisome proliferator-activated receptor-gamma: therapeutic target for diseases beyond diabetes: quo vadis? Expert Opin Investig Drugs. 2004;13:215-228.

37. Giaginis C, Tsantili-Kakoulidou A, Theocharis S. Peroxisome proliferator-activated receptor-gamma ligands: potential pharmacological agents for targeting the angiogenesis signaling cascade in cancer. PPAR Res. 2008:431763.

38. Rosmarakis ES, Falagas ME. Effect of thiazolidinedione therapy on restenosis after coronary stent implantation: a meta-analysis of randomized controlled trials. Am Heart J. 2007;154:144-150.

39. Desouza CV, Gerety M, Hamel FG. Long-term effects of a PPAR-gamma agonist, pioglitazone, on neointimal hyperplasia and endothelial regrowth in insulin resistant rats. Vascul Pharmacol. 2007;46: 188-194.

40. Panigrahy D, Singer S, Shen LQ, et al. PPARgamma ligands inhibit primary tumor growth and metastasis by inhibiting angiogenesis. J Clin Invest. 2002;110:923-932.

41. Sheu WH, Ou HC, Chou FP, Lin TM, Yang CH. Rosiglitazone inhibits endothelial proliferation and angiogenesis. Life Sci. 2006;78:1520-1528.

42. Bishop-Bailey D, Hla T. Endothelial cell apoptosis induced by the peroxisome proliferator-activated receptor (PPAR) ligand 15-deoxy-Delta12, 14-prostaglandin J2. J Biol Chem. 1999;274: 17042-17048.

43. Giri S, Rattan R, SinghAK, Singh I. The 15-deoxy-delta12,14-prostaglandin $\mathrm{J} 2$ inhibits the inflammatory response in primary rat astrocytes via down-regulating multiple steps in phosphatidylinositol 3-kinase-Akt-NFkappaB-p300 pathway independent of peroxisome proliferator-activated receptor gamma. J Immunol. 2004;173:5196-5208.

44. Aljada A, O’Connor L, Fu YY, Mousa SA. PPAR gamma ligands, rosiglitazone and pioglitazone, inhibit bFGF- and VEGF-mediated angiogenesis. Angiogenesis. 2008;11:361-367.

45. Cho DH, Choi YJ, Jo SA, Jo I. Nitric oxide production and regulation of endothelial nitric-oxide synthase phosphorylation by prolonged treatment with troglitazone: evidence for involvement of peroxisome proliferator-activated receptor (PPAR) gamma-dependent and PPARgamma-independent signaling pathways. J Biol Chem. 2004;279:2499-2506.

46. Chintalgattu V, Harris GS, Akula SM, Katwa LC. PPAR-gamma agonists induce the expression of VEGF and its receptors in cultured cardiac myofibroblasts. Cardiovasc Res. 2007;74:140-150. 
47. Gealekman O, Burkart A, Chouinard M, Nicoloro SM, Straubhaar J, Corvera S. Enhanced angiogenesis in obesity and in response to PPARgamma activators through adipocyte VEGF and ANGPTL4 production. Am J Physiol Endocrinol Metab. 2008;295:E1056-E1064.

48. Chu K, Lee ST, Koo JS, et al. Peroxisome proliferator-activated receptor-gamma-agonist, rosiglitazone, promotes angiogenesis after focal cerebral ischemia. Brain Res. 2006;1093:208-218.

49. Huang PH, Sata M, Nishimatsu H, Sumi M, Hirata Y, Nagai R. Pioglitazone ameliorates endothelial dysfunction and restores ischemiainduced angiogenesis in diabetic mice. Biomed Pharmacother. 2008;62:46-52.

50. Gensch C, Clever YP, Werner C, Hanhoun M, Bohm M, Laufs U. The PPAR-gamma agonist pioglitazone increases neoangiogenesis and prevents apoptosis of endothelial progenitor cells. Atherosclerosis. 2007;192:67-74.

51. Vijay SK, Mishra M, Kumar H, Tripathi K. Effect of pioglitazone and rosiglitazone on mediators of endothelial dysfunction, markers of angiogenesis and inflammatory cytokines in type-2 diabetes. Acta Diabetol. 2009;46:27-33.

52. Fong DS, Contreras R. Glitazone use associated with diabetic macular edema. Am J Ophthalmol. 2009;147:583-586 e1.

53. Finck BN, Kelly DP. Peroxisome proliferator-activated receptor gamma coactivator-1 (PGC-1) regulatory cascade in cardiac physiology and disease. Circulation. 2007;115:2540-2548.

54. Arany Z, Foo SY, Ma Y, et al. HIF-independent regulation of VEGF and angiogenesis by the transcriptional coactivator PGC-1alpha. Nature. 2008;451:1008-1012.

55. Hickey MM, Simon MC. Regulation of angiogenesis by hypoxia and hypoxia-inducible factors. Curr Top Dev Biol. 2006;76:217-257.

56. Lee KS, Kim SR, Park SJ, et al. Peroxisome proliferator activated receptor-gamma modulates reactive oxygen species generation and activation of nuclear factor-kappaB and hypoxia-inducible factor 1 alpha in allergic airway disease of mice. J Allergy Clin Immunol. 2006;118:120-127.

57. Chen J, Cui X, Zacharek A, Roberts C, Chopp M. eNOS mediates TO90317 treatment-induced angiogenesis and functional outcome after stroke in mice. Stroke. 2009;40:2532-2538.

58. Howell K, Costello CM, Sands M, Dooley I, McLoughlin P. L-arginine promotes angiogenesis in the chronically hypoxic lung: a novel mechanism ameliorating pulmonary hypertension. Am J Physiol Lung Cell Mol Physiol. 2009;296:L1042-L1050.

59. Namkoong S, Kim CK, Cho YL, et al. Forskolin increases angiogenesis through the coordinated cross-talk of PKA-dependent VEGF expression and Epac-mediated PI3K/Akt/eNOS signaling. Cell Signal. 2009;21:906-915.
60. Yasuda S, Kobayashi H, Iwasa M, et al. Antidiabetic drug pioglitazone protects the heart via activation of PPAR-\{gamma $\}$ receptors, PI3-kinase, Akt, and eNOS pathway in a rabbit model of myocardial infarction. Am J Physiol Heart Circ Physiol. 2009;296: H1558-H1565.

61. Bulhak AA, Jung C, Ostenson CG, Lundberg JO, Sjoquist PO, Pernow J. PPAR-alpha activation protects the type 2 diabetic myocardium against ischemia-reperfusion injury: involvement of the PI3-Kinase/ Akt and NO pathway. Am J Physiol Heart Circ Physiol. 2009;296: H719-H727.

62. Cuzzocrea S, Pisano B, Dugo L, et al. Rosiglitazone, a ligand of the peroxisome proliferator-activated receptor-gamma, reduces acute inflammation. Eur J Pharmacol. 2004;483:79-93.

63. Tao L, Liu HR, Gao E, et al. Antioxidative, antinitrative, and vasculoprotective effects of a peroxisome proliferator-activated receptorgamma agonist in hypercholesterolemia. Circulation. 2003;108: 2805-2811.

64. Pedchenko TV, Gonzalez AL, Wang D, DuBois RN, Massion PP. Peroxisome proliferator-activated receptor beta/delta expression and activation in lung cancer. Am J Respir Cell Mol Biol. 2008;39: 689-696.

65. Ma J, Sawai H, Ochi N, et al. PTEN regulate angiogenesis through $\mathrm{PI} 3 \mathrm{~K} / \mathrm{Akt} / \mathrm{VEGF}$ signaling pathway in human pancreatic cancer cells. Mol Cell Biochem. 2009; May 13. [Epub ahead of print].

66. Panigrahy D, Kaipainen A, Huang S, et al. PPARalpha agonist fenofibrate suppresses tumor growth through direct and indirect angiogenesis inhibition. Proc Natl Acad Sci US A. 2008;105:985-990.

67. Minutoli L, Antonuccio P, Polito F, et al. Peroxisome proliferator activated receptor beta/delta activation prevents extracellular regulated kinase $1 / 2$ phosphorylation and protects the testis from ischemia and reperfusion injury. J Urol. 2009;181:1913-1921.

68. Lim HJ, Lee S, Park JH, et al. PPAR delta agonist L-165041 inhibits rat vascular smooth muscle cell proliferation and migration via inhibition of cell cycle. Atherosclerosis. 2009;202:446-454.

69. Borland MG, Foreman JE, Girroir EE, et al. Ligand activation of peroxisome proliferator-activated receptor-beta/delta inhibits cell proliferation in human HaCaT keratinocytes. Mol Pharmacol. 2008;74:1429-1442.

70. Piqueras L, Sanz MJ, Perretti M, et al. Activation of PPAR $\{$ beta $\} /\{$ delta $\}$ inhibits leukocyte recruitment, cell adhesion molecule expression, and chemokine release. J Leukoc Biol. 2009;86:115-122.

\section{Publish your work in this journal}

Diabetes, Metabolic Syndrome and Obesity: Targets and Therapy is an international, peer-reviewed open-access journal committed to the rapid publication of the latest laboratory and clinical findings in the fields of diabetes, metabolic syndrome and obesity research. Original research, review, case reports, hypothesis formation, expert opinion and commentaries are all considered for publication. The manuscript management system is completely online and includes a very quick and fair peer-review system, which is all easy to use. Visit http://www.dovepress.com/testimonials.php to read real quotes from published authors. 